\title{
Prevalence of anti-hepatits A antibodies in children of different socioeconomic conditions in Vila Velha, ES
}

\author{
Prevalência de anticorpos anti-hepatite A em crianças de diferentes condições \\ sócioeconômicas em Vila Velha, Estado do Espírito Santo
}

\author{
Maria P. Zago-Gomes ${ }^{1}$, Gustavo C. Stantolin ${ }^{1}$, Sandro Perazzio ${ }^{1}$, Kioshi H. Aikawa ${ }^{1}$, \\ Carlos S. Gonçalves ${ }^{1}$ and Fausto E.L. Pereira ${ }^{1}$
}

\begin{abstract}
This report describes the prevalence of anti-HAV antibodies in children from elementary school in the Municipality of Vila Velha, ES, Brazil. Anti-HAV antibodies were investigated by ELISA method in the serum of 606 children (four to fourteen years old) from three elementary schools, located in neighborhoods with varying household monthly income levels: São José School, 200 chidren, household income higher than US\$700; São Torquato School, 273 children, US\$200 to 300; and Cobi School, 133 children, less than US\$200. From each children data on age, gender, skin color, sanitary conditions, frequency of contact with sea or river water and family history of hepatitis were recorded. Anti-HAV antibodies were present in $38.6 \%$ of all children, $9 \%$ in São José School, 49.1\% in São Torquato School and 61.7\% in Cobi School. Logistic regression analysis demonstrated a positive correlation of positive anti-HAV test with age, non white color of the skin, absence of sewage treatment and domestic water filter, and a past history of hepatitis. The prevalence of anti-HAV antibodies in school children in Vila Velha, ES, was lower than that observed in the same age group in North and Northeast Brazil and was significantly higher in children from families with low socioeconomic status. In addition the results indicate a changing epidemiologic pattern of hepatitis Ain our country, with an increasing number of children and adolescents with high risk for HAVinfection, mainly in high socioeconomic class. A consideration must be given to the feasibility of vaccination programs for children and adolescents in our country.
\end{abstract}

Key-words: Hepatitis A. Hepatitis. Hepatitis A virus. Brazil.

\section{RESUMO}

É descrita a prevalência de anticorpos antivírus da hepatite A em crianças de diferentes condições socioeconômicas matriculadas em escolas de ensino fundamental no Município de Vila Velha, na região metropolitana de Vitória, Estado do Espírito Santo. Os anticorpos anti-VHA foram pesquisados por ELISA no soro de 606 crianças ( quatro a catorze anos de idade) de escolas fundamentais localizadas em bairros com diferentes rendas familiares: Escola São José, 200 crianças, renda familiar acima de US\$700; Escola São Torquato, 273 crianças renda familiar entre US\$200 e US\$300; e Escola Cobi, 133 crianças, renda familiar menor do que US\$200. De cada criança foram tomados dados sobre idade, sexo, cor da pele, condições sanitárias, freqüência de contacto com água de rio ou de mar e história de hepatite na família. Anticorpos anti-VHA estavam presentes em 38,6\% de todas as crianças, 9\% na Escola São José, 49,1\% na Escola São Torquato e 61,7\% na Escola Cobi. Análise de regressão logística demonstrou correlação entre o teste anti-HAV positivo com idade, pele preta ou mulata, ausência de esgoto domiciliar e de água filtrada e história de hepatite na família. A prevalência de anticorpos anti-HAV em Vila Velha foi menor do que a observada, no mesmo grupo etário, no Norte e Nordeste do Brasil, e foi maior nas crianças de piores condições socioeconômicas. Também, os dados indicam uma mudança no perfil epidemiológico da hepatite Ano nosso meio, com um aumento do número de crianças e adolescentes com alto risco de infecção, especialmente nas classes socioeconômicas mais altas. Deve-se discutir a necessidade de vacinação para hepatite A nas crianças e adolescentes no nosso meio.

Palavras-chaves: hepatite A. Hepatite. Vírus da hepatite A. Brasil.

1. Núcleo de Doenças Infecciosas do Centro Biomédico da Universidade Federal do Espírito Santo, Vitória, ES, Brazil.

Address to: Dr. Fausto E.L. Pereira. Núcleo de Doenças Infecciosas. Centro Biomédico/UFES. Av. Marechal Campos 1468, 29040-091 Vitória, ES, Brasil.

Tel: 5527 3335-7206

e-mail: felp@ndi.ufes.br

Recebido para publicação em 3/2/2004

Aceito em 28/4/2005 
The prevalence of hepatitis A infection varies according to hygienic conditions, being very high in developing countries where the majority of infections are clinically undetected, and have low or no significant morbidity. With improvement in hygienic conditions, these countries may enter a transition phase in which the virus is prevalent but the infection occurs in older individuals, like in areas of the world with high hygiene standards. This older susceptible population is more likely to experience morbidity when infected leading to a greater risk of symptomatic diseases ${ }^{11} 121327$.

The publications on the prevalence of hepatitis A in Brazil 1346810142122232425262829303132 have shown high prevalence in the North, Northeast and Central-West regions (the less developed regions of Brazil) and intermediate or low prevalence in the Southeast and South (more developed regions). They demonstrate the relationship between the prevalence of hepatitis A infection and the socioeconomic status of the sample for Brazil (data summarized in Table 1). In this way, the average age of infection is increasing in the South and Southeast regions, increasing the number of people at risk of symptomatic HAV infection and the rise of a significant public health problem.

Table 1 - Summary of reports on hepatitis Aprevalence in different areas of Brazil, from 1984 through 2002.

\begin{tabular}{|c|c|c|c|}
\hline \multirow[t]{2}{*}{ Author } & \multirow[t]{2}{*}{ City, State or Region } & \multicolumn{2}{|c|}{$\begin{array}{c}\text { Positive for anti-HAV( } \%) \\
\text { age ( years) }\end{array}$} \\
\hline & & age $<10$ & age $>10$ \\
\hline Gayotto et al ${ }^{14}$ & Amazon Region & 73.3 & 95 \\
\hline Pannutti et al ${ }^{22}$ & São Paulo, SP & $40.3 * / 75^{* *}$ & 91.9 \\
\hline Abuzwalda et al ${ }^{1}$ & Rio de Janeiro, RJ & $40 * / 90 * *$ & $>90 / 90$ \\
\hline Yoshida et al ${ }^{32}$ & Rio de Janeiro, RJ & $\mathrm{NA}$ & 97 \\
\hline Oliveira et al ${ }^{21}$ & Rio de Janeiro, RJ & $\mathrm{NA}$ & 54.3 \\
\hline Queiroz et al ${ }^{25}$ & Goiânia, GO & 80 & 92.9 \\
\hline Queiroz et $\mathrm{al}^{26}$ & Goiânia, G0 & 69.7 & $\mathrm{NA}$ \\
\hline Ferreira et $a^{18}$ & Porto Alegre, RS & $7 * / 53^{* *}$ & $17 * / 71 * *$ \\
\hline Pinho et $\mathrm{al}^{24}$ & Campinas, SP & $\mathrm{NA}$ & $19.6^{*} / 95^{* *}$ \\
\hline Vitral et al ${ }^{31}$ & Rio de Janeiro, RJ & $34 \%$ & 66 \\
\hline Focaccia et al ${ }^{10}$ & São Paulo, SP & $28 \%$ & 56 \\
\hline Struchiner et al ${ }^{28}$ & Rio de Janeiro, RJ & $12 * / 36.6 * *$ & $\mathrm{NA}$ \\
\hline \multirow[t]{4}{*}{ Clemens et al ${ }^{6}$} & Manaus, AM & $\mathrm{NA}$ & 92.6 \\
\hline & Fortaleza, CE & $\mathrm{NA}$ & 76.5 \\
\hline & Rio de Janeiro, RJ & $\mathrm{NA}$ & 55.7 \\
\hline & Porto Alegre, RS & $\mathrm{NA}$ & 55.7 \\
\hline Paula et $\mathrm{al}^{23}$ & Amazon Region & 90 & 93.7 \\
\hline Trinta et al ${ }^{29}$ & Rio de Janeiro, RJ & 7\#38.1\#\# & 95\#93\%\#\# \\
\hline Villar et al $1^{30}$ & Rio de Janeiro, RJ & $\mathrm{NA}$ & 54.02 \\
\hline Assis et $a^{14}$ & Peixoto Azevedo, MT & 86.4 & NA \\
\hline Almeida et al ${ }^{23}$ & Duque de Caxias, RJ & 60.3 & 89.4 \\
\hline
\end{tabular}

* high socioeconomic class; ** low socioeconomic; \# urban population; \#\# rural population; NA not available.

In Espirito Santo, a State in Southeast Brazil, there are no reports on the prevalence of hepatitis A virus (HAV) infection in the general population, but acute hepatitis $\mathrm{A}$ is frequent in children. It is the main cause of severe acute hepatitis diagnosed at a reference Children's Hospital in Vitória, the capital of the state $^{20}$. For this reason we suspected that the prevalence of hepatitis A infection would be intermediate, especially in higher socioeconomic classes, in which the risk of infection would be shifting to older children and young adults. The detection of this shift is relevant for public health measures because the infection can be prevented with a vaccine.

This report describes age specific anti-HAV prevalence among school children 6 to 14 years old, living in three neighborhoods with different socioeconomic status, in the city of Vila Velha, one of the cities of Metropolitan Vitória.

\section{MATERIAL AND METHODS}

Study sample. The survey was performed in the City of Vila Velha, one of the municipalities that forms the metropolitan Vitória (Figure 1). The city has 346,878 inhabitants ${ }^{17}$, living in the urban periphery (low our low-middle socioeconomic status) and in the downtown, near the beach ( high socioeconomic status).

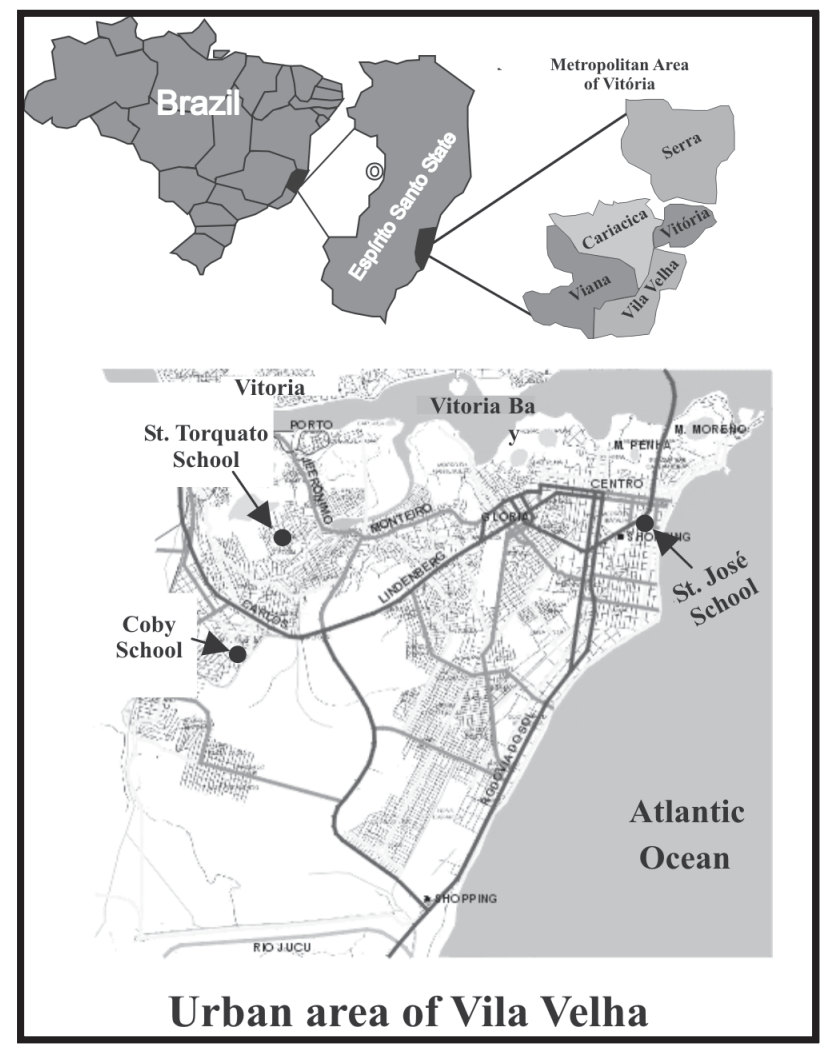

Figure 1 - Map of the Metropolitan Area of Vitória and the urban area of the City of Vilha Velha showing the location of the three elementary schools of the children enrolled in the study.

The sample was made up of 606 children enrolled in one of three elementary schools: (a) 200 children from one private school ( São José School), located in the downtown area where children are from families with monthly income higher than US\$700; (b) 273 children from a public school located in the area of São Torquato (São Torquato School), where children are from families with monthly income ranging from US\$200 to US\$300; and (c) 133 children from a public school located in Cobi (Cobi School) where children are from families with monthly income less than US $\$ 200$. 
This sample size is based on an expected infection rate of a least $70 \%$ in children of $7-10$ years of age in developing countries.

Signed informed consent was obtained from the parents of the children. A questionnaire for sociodemographic data and previous exposures and illnesses was administered to parents and children, and all children were submitted to a clinical examination for evaluation of nutritional status. A $5 \mathrm{ml}$ blood sample was obtained and the sera stored at $-20^{\circ} \mathrm{C}$.

Laboratory procedures. Serum samples were analysed for total anti-HAV using a commercial enzyme-linked immunosorbent assay kit (Hepanostik HAV Antibody, Organon Teknika, Baxtel, Netherlands), according to manufacturer's instructions.

Data analysis. For analysis the SPSS version 10.0 for Windows was used. Seroprevalence was stratified by school, according to age group, with calculation of $95 \%$ confidence intervals. The socioeconomic status was defined by family income and was confirmed by differences in body mass index and in skin color distribution. The odds-ratio with 95\% confidence interval was calculated for the association with the different risk factors. Multivariate analysis by logistic regression was used to adjust for various risk factors of HAV infection.

\section{RESULTS}

The main sociodemographic data of the three samples studied are displayed in Table 2. There is no difference in gender distribution among the samples, but the number of children over ten years old is greater in the two schools of lower socioeconomic status. The significant differences observed in regard to availability of treated water (use of domestic filter), sewage facilities and body mass index confirm the expected socioeconomic differences among the three samples studied.

The results of the serology for total anti-HAV antibodies are displayed in Table 3. There is significant difference between the prevalence of positive serology in children from the families with higher incomes ( São José School) and the two groups of children belonging to families with low-middle or low incomes. The agespecific anti-HAV prevalence (with 95\% CI) are displayed in Figure 2 , and demonstrate significant differences between the children with high socioeconomic status ( São José School) in comparison with the children of the low-middle or low socioeconomic status. Multivariate analysis by logistic regression ( Table 4) demonstrate that age, black color of skin, absence of domestic water filter, absence of sewage system and a past history of hepatitis were significantly associated with a positive anti-HAV serology.

\begin{tabular}{|c|c|c|c|c|c|}
\hline Variables & St José school & St Torquato school & Cobi school & Total & $\mathrm{p}$ \\
\hline \multicolumn{6}{|l|}{ Gender } \\
\hline male & $104(52.0 \%)$ & $122(44.6 \%)$ & 67 (51.4\%) & 293 (48.3\%) & \\
\hline female & $96(48.0 \%)$ & $151(55.4 \%)$ & 66 (48.6\%) & 313 (51.7\%) & 0.211 \\
\hline \multicolumn{6}{|l|}{ Age ( years) } \\
\hline 6 & 9 & 32 & 41 & 82 & \\
\hline 7 & 42 & 53 & 21 & 116 & \\
\hline 8 & 59 & 47 & 18 & 124 & \\
\hline 9 & 56 & 50 & 8 & 114 & \\
\hline 10 & 33 & 52 & 16 & 101 & \\
\hline 11 & 1 & 17 & 12 & 30 & \\
\hline 12 & - & 15 & 11 & 26 & \\
\hline$>12$ & - & 6 & 7 & 13 & 0.000 \\
\hline \multicolumn{6}{|l|}{ Skin color } \\
\hline white & $123(61.8 \%)$ & 97 (35.5\%) & $36(27.1 \%)$ & $256(42.3 \%)$ & \\
\hline mulatto & $70(35.1 \%)$ & $136(49.8 \%)$ & $57(42.8 \%)$ & $263(43.5 \%)$ & \\
\hline negro & $6(3.0 \%)$ & $40(14.6 \%)$ & $40(30.1 \%)$ & $86(14.2 \%)$ & 0.000 \\
\hline \multicolumn{6}{|c|}{ Use of filtered water } \\
\hline yes & $200(100.0 \%)$ & $196(72.3 \%)$ & $50(37.5 \%)$ & $446(73.8 \%)$ & \\
\hline no & 0 & 75 (27.7\%) & $83(62.5 \%)$ & $158(26.2 \%)$ & 0.000 \\
\hline \multicolumn{6}{|c|}{ Sewages facilities } \\
\hline yes & $200(100.0 \%)$ & $185(720.6 \%)$ & $32(24.6 \%)$ & $417(70.4 \%)$ & \\
\hline no & 0 & 77 (29.3\%) & 98 (75.4\%) & $175(29.6 \%)$ & 0.000 \\
\hline \multicolumn{6}{|c|}{ River or sea swimming } \\
\hline yes & $120(60.0 \%)$ & $94(34.5 \%)$ & $45(33.8 \%)$ & $259(42.7 \%)$ & \\
\hline no & $80(40.0 \%)$ & $179(65.5 \%)$ & 88 (66.2\%) & 347 (57.3\%) & 0.000 \\
\hline \multicolumn{6}{|c|}{ Persons living in home } \\
\hline $1-3$ & $119(59.7 \%)$ & $118(43.3 \%)$ & $45(33.8 \%)$ & $282(46.6 \%)$ & \\
\hline $4-6$ & 62 (31.1\%) & $99(36.2 \%)$ & 60 (45.1\%) & $221(36.5 \%)$ & \\
\hline$>7$ & $18(9.1 \%)$ & 55 (20.1\%) & $28(21.0 \%)$ & $101(16.7 \%)$ & 0.000 \\
\hline
\end{tabular}


Table 3 - Anti-HAV antibodies in children from three elementary schools in the Municipality of Vila Velha, ES, Brazil.

\begin{tabular}{lrrrrrr}
\hline & \multicolumn{5}{c}{ Anti-HAV } \\
\cline { 2 - 3 } & \multicolumn{2}{c}{ positive } & & \multicolumn{2}{c}{ negative } & \\
\cline { 2 - 3 } School & $\mathrm{n}^{0}$ & $\%$ & $\mathrm{n}^{0}$ & $\%$ & Total \\
\hline São José*a & 18 & 9.0 & 182 & 91.0 & 200 \\
St Torquato**b & 134 & 49.1 & 139 & 50.9 & 273 \\
Cobi*** & 82 & 61.7 & & 51 & 38.3 & 133 \\
\hline Total & 234 & 38.6 & 372 & 61.4 & 606 \\
\hline
\end{tabular}

Socioeconomic status: * high, ${ }^{* *}$ low-middle and ${ }^{* * *}$ low

a: $p=0,000$ compared to St Torquato and Cobi;

b: $p=0,017$ compared to Cobi.

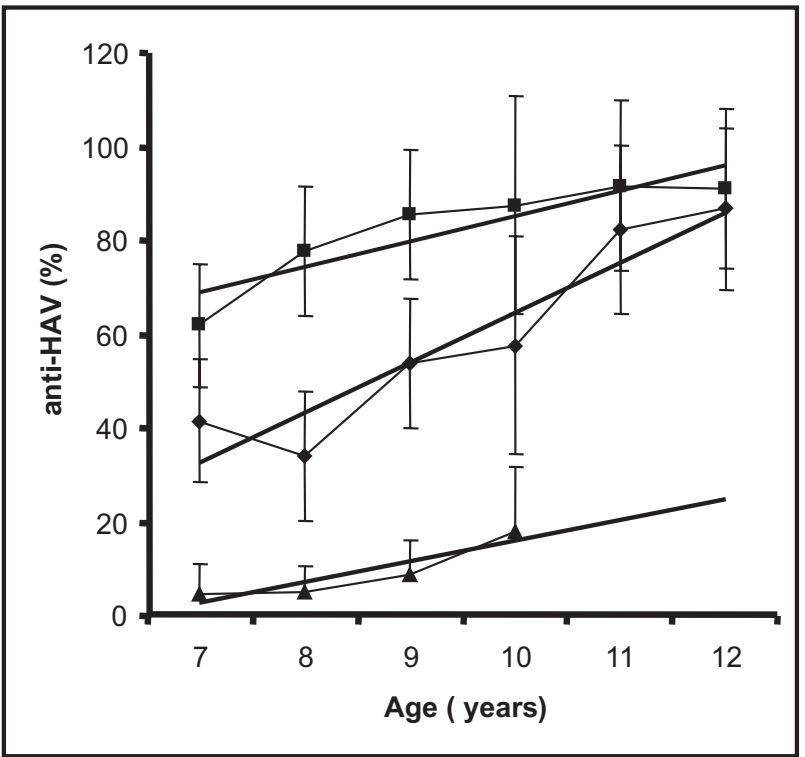

Children with low socioeconomic status (Cobi school). $\bullet$ Children with low-middle socioeconomic status (St Torquato school). $\mathbf{\Delta}$ Children with high socioeconomic status ( St José school). Vertical lines indicate the 95\% confidence intervals.

Figure 2- Age distribution (with tendency lines) of positive antiHAV antibodies in children from three elementary schools of the City of Vila Velha, ES, Brazil.

\section{DISCUSSION}

The three samples studied are representative of 7 to 11 year old children living in Vila Velha because, according to the Education Department of the Municipality, 98\% of children in this age group are enrolled in elementary school. In addition, the significant differences in regard to the number of people living at each home, the presence of sewage systems, utilization of water filter, body mass index and color of skin confirm the socioeconomic differences of the three samples studied. The gender distribution was similar in the three samples. The differences in regard to age were due to the greater number of children from low socioeconomic families that did not pass the elementary school examinations.

The prevalence of anti-HAV positive serology observed for all children (38.6\%) was lower than that reported in North and Centerwest ${ }^{146142232}$ and was more similar to that reported
Table 4- Multivariate analysis by logistic regression of anti-HAVrisk factors in children enrolled in three elementary schools in the City of Vila Velha, ES, Brazil.

\begin{tabular}{lccc}
\hline Variables & OR & $95 \%$ CI & p \\
\hline Age (years) & & & \\
7 & 2.086 & $1.085-4.013$ & 0.028 \\
8 & 2.704 & $1,411-5.181$ & 0.003 \\
9 & 1.802 & $0.948-3.427$ & 0.072 \\
10 & reference & & \\
Gender & & & \\
female & 0.810 & $0.512-1.228$ & 0.369 \\
$\quad$ male & reference & & \\
Skin colour & & & \\
white & 0.409 & $0.253-0.660$ & 0.000 \\
$\quad$ negro or mulattoe & reference & & \\
Positive answer to & & & \\
domestic water filter & 0.308 & $0.171-0.552$ & 0.000 \\
sewages facilities & 0.430 & $0.267-0.719$ & 0.001 \\
river swimming & 0.672 & $0.420-1.076$ & 0.098 \\
sea swimming & 0.570 & $0.203-1.598$ & 0.285 \\
more than four persons in home & 1.445 & $0.913-2.289$ & 0.116 \\
past history of hepatitis & 3.019 & $1.006-9.057$ & 0.049 \\
past history of surgery & 0.695 & $0.334-1.414$ & 0.329 \\
past history of blood transfusion & 4.642 & $0.926-23.276$ & 0.062 \\
hepatitis in family & 2.114 & $0.859-5.200$ & 0.103 \\
\hline
\end{tabular}

in Southeastand South Brazil ${ }^{36810232428293031}$. When the prevalence of a positive serology for anti-HAV is stratified by socioeconomic status, the differences observed are significant. There is a higher prevalence in children from Cobi (low socioeconomic status) and São Torquato (middle-low socioeconomic status) schools than in children from São José school (high socioeconomic status). In addition, the prevalence of positive serology in children seven years of age or less in all socioeconomic levels was lower than that reported for highly endemic areas.

However, even when we considered only the children from low or low-middle socioeconomic status, the prevalence of anti-HAV antibodies in children seven years of age or less is still lower than that reported in North and Center-West Brazil, areas of very high incidence of HAV infection ${ }^{114} 2122252632$.

The correlation between positive anti-HAV serology and various factors including age, low socioeconomic status, absence of sewage facilities, domestic water filter and a past history of hepatitis in the family supports similar findings elsewhere in the world ${ }^{51819}$ as well as in Brazil ${ }^{3}$. As reported in Chile ${ }^{9}$, swimming in the sea or a river, was not positively associated with the presence of anti-HAV antibodies.

Taken together these results demonstrate in Vila Velha a pattern of HAV infection characterized by an increasing number of susceptible children, especially in high or lowmiddle socioeconomic status. Considering that Brazil has been considered a country of very high prevalence of HAV infection, according to the map published by the Centers for Disease Control, USA ${ }^{7}$, our results suggest that we may need to reconsider the pattern of this infection. The pattern appears to be changing in recent years like in other more rapidly developing countries and cities 815162427 . 
There remains little information on the frequency of clinically apparent HAV infection in adolescents and young adults in Vila Velha or Vitória, although the high frequency of clinically apparent cases, including severe forms of the disease, diagnosed at the Children's Hospital in Vitória may be a partial marker. This is in concordance with the results of our study and further supports our hypothesis that the pattern of HAVinfection is changing in our country.

The result of this new pattern of prevalence is a high number of susceptible children living near areas where the virus is clearly still prevalent, putting these children in a situation similar to travelers from non-endemic to endemic areas. In this context, consideration must be given to the feasibility of vaccination programs for children and adolescents in our country. This would require further study of the cost-benefit ratio of this strategy in developing countries ${ }^{6}$.

\section{REFERENCES}

1. Abuzwaida ARN, Sidoni M, Yoshida CFT, Schatzmayr HG. Seroepidemiology of hepatitis A and B in two urban communities of Rio de Janeiro, Brazil. Revista do Instituto de Medicina Tropical de São Paulo 29:219-223, 1987.

2. Almeida LM, Amaku M, Azevedo RS, Caimcross S, Massad E. The intensity of transmission of hepatitis A and heterogeneties in socio-economic risk factors in Rio de Janeiro, Brazil. Transactions of the Royal Society of Tropical Medicine and Hygiene 96:605-619, 2002.

3. Almeida LM, Werneck GL, Caimcross S, Coeli CM, Costa MCE, Coletty PE. The epidemiology of hepatitis A in Rio de Janeiro: environmental and domestic risk factors. Epidemiology and Infection 17:327-333, 2001.

4. Assis SB, Souto FDS, Fontes CJF, Gaspar AMC. Prevalência da infecção pelos vírus das hapatites A e E em escolares do município da Amazônia Matogrossense. Revista da Sociedade Brasileira de Medicina Tropical 35:155-158, 2002.

5. Beutels P, Edmunds WJ, Antonanzas F, De Wit GA, Evans D, Feilden R, Fendrick AM, Ginsberg GM, Glick HÁ, Mast E, Pechevis M, Van Doorslaer EK, van Hout BA. Viral Hepatitis Prevention Board. Economic evaluation of vaccination programs: a consensus statement focusing on viral hepatitis. Pharmacoeconomics 20:1-7, 2002.

6. Clemens AS, Fonseca JC, Azevedo T, Cavalcanti A, Silveira TR, Castilho MC, Clemens R. Soroprelalência para hepatite A e B em quatro centros no Brasil. Revista da Sociedade Brasileira de Medicina Tropical 33:1-10, 2000.

7. Feinstone SM, Gust ID. Hepatitis A virus In: Mandell GL, Bennet JE, Dolin R (eds) Principles and Practice of Infectious Disease. New York, Churchill Livingstone p.1920-1940, 2000.

8. Ferreira CT, Silva GLS, Barros FC, Lima JP. Serum epidemiology Hepatitis A virus in two socioeconomically distinct populations groups of Porto Alegre. Gastroenterologia e Endoscopia Digestiva 15:85-90, 1996.

9. Fix AD, Martin OS, Gallicchio L, Vial PA, Lagos R. Age specific prevalence of antibodies to hepatitis A in Santiago, Chile: Risk factors and shift in age of infection among children and young adults. American Journal of Tropical Medicine and Hygiene 66:628-632, 2002.

10. Focaccia R, Conceição OJG, Sette Jr H, Sabino E, Bassit L, Nitrini DR, Lomar AV, Lorenço R, Souza FV, Kiffer CRV, Santos EB, Gonzales MP, Saéz-Aquézar A, Riscal JR, Fischer D. Estimated prevalence of viral hepatitis in the general population of the municipality of São Paulo, measured by a serologic survey of a stratified, randomized and residence-based populatin. Brazilian Journal of Infectious Diseases 2:269-284, 1998.

11. Forbes A, Williams R. Increasing age: an important adverse prognostic factor in hepatitis A virus infection. Journal of the Royal College of Physicians (London) 22:237-239, 1988.

12. Forbes A, Williams R. Changing epidemiology and clinical aspects of hepatitis A. British Medical Bulletin 46:303-318, 1990.

13. Gay N, Morgan-Capner P, Wright J, Farrington CP, Miller E. Age-specific antibody prevalence to hepatitis A in England: implications for disease control. Epidemiology and Infection 113:113-120, 1994.
14. Gayotto LC, Quarentei AA, Cabral GL. Soroepidemiologia das hepatites A e B nas regiões dos rios Biá e Alto Juruá, Amazônia Ocidental. Gastroenterologia e Endoscopia Digestiva 3:106-112, 1984.

15. Green MS, Cohen D, Stepon R, Handsher R, Zaaide Y, Rannon L, Danon Y. Sociodemographic correlates of neutralizing poliovirus and hepatitis A virus antibodies as markers of different modes of acquiring immunity. American Journal of Public Health 80:1270-1271, 1990.

16. Gust ID. Epidemiological patterns of hepatitis A in different parts of the world. Vaccine 10 ( supl 1):S56-58, 1992.

17. Instituto Brasileiro de Geografia e Estatística (IBGE) . Base de informações por setor censitário. Censo Demográfico 2000. Resultados do Universo, Espírito Santo, Vila Velha. CD-ROM, ISBN 85-240-0976-878, 2002.

18. Kosuwan P, Sutran S, Kosalaraksa P, Poovorawan Y. Seroepidemiology of hepatitis A virus antibody in primary school children in Khon Kaen Province, northeastern. Thailand. Southeast Asian Journal of Tropical Medicine and Public Healh 27:650-653, 1996.

19. Morales JL, Huber L, Gallego S, Alvares G, Diez-Delgado J, Gonzales A, Aquilar L, Dal-Re R. A seroepidemiologic study of hepatitis A in Spanish children. Relationship of prevalence to age and socio-environmental factors. Infection 20:194-196, 1992.

20. Moreira-Silva SF, Frauches DO, Almeida AL, Mendonça HFM, Pereira FEL. Acute liver failure in children: observations in Vitória, E Santo State, Brazil. Revista da Sociedade Brasileira de Medicina Tropical 35:483-486, 2002.

21. Oliveira LHS, Yoshida CFT, Monteiro SS, Câmara FP. Seroepidemiologic survey for hepatitis A and B markers in health care students from a Public University of Rio de Janeiro, Brazil. Revista de Microbiologia 22:226-231, 1991.

22. Pannuti CS, Mendonça JS, Carvalho MJM, Oselka GW, Amato Neto V. Hepatitis A antibodies in two socioeconomically distinct populations of São Paulo, Brazil. Revista do Instituto de Medicina Tropical de São Paulo 27:162-164, 1985.

23. Paula VS, Arruda ME, Vitral CI, Gaspar AMC. Seroprevalence of Viral Hepatitis in Riverine Communities from the Western Region of the Brazilian Amazon Basin. Memórias do Instituto Oswaldo Cruz 96:1123-1128, 2001.

24. Pinho JRR, Sumita LM, Moreira RC, Souza VAF, Saraceni CP, Oba IT, Carvalho MCS, Pannuti CS. Duality of patterns in hepatitis A epidemiology: a study involving two socioeconomically distinctpopulations in Campinas, São Paulo State, Brazil. Revista do Instituto de Medicina Tropical de São Paulo 40:105-106, 1998.

25. Queiróz DAO, Cardoso DDP, Martelli CMT, Martins RMB, Porto SOB, Azevedo MSP, Borges AMT, Daher RR. Risk factor and prevalence of antibodies against hepatitis A virus ( HAV) in children from day-care centers, in Goiânia, Brazil. Revista do Instituto de Medicina Tropical de São Paulo 37:427-433, 1995.

26. Queiróz DAO, Cardoso DDP, Martelli CMT, Martins RMB, Porto SOB, Azevedo MSP, Borges AMT, Daher RR. Soroepidemiologia da infeç̧ão pelo vírus da hepatite A em "Meninos de/na Rua" de Goiânia-Goias. Revista da Sociedade Brasileira de Medicina Tropical 28:199-203, 1995.

27. Shapiro CN, Margolis HS. Worldwide epidemiology of hepatitis A virus infection. Journal of Hepatology 18 ( supl 2):S11-14, 1993.

28. Struchiner CJ, Almeida LM, Azevedo RS, Massad E. Hepatitis A incidence rate estimates from a pilot seroprevalence survey in Rio de Janeiro, Brazil. International Journal of Epidemiology 28:776-781, 1999.

29. Trinta KS, Liberto MIM, Paula VS, Yoshida CFT, Gaspar AMC. Hepatitis E virus infection in selected brazilian populations. Memórias do Instituto Oswaldo Cruz 96:25-29, 2001.

30. Villar LM, Costa MCE, Paula VS, Coimbra AM. Hepatitis A Outbreak in a Public School in Rio de Janeiro, Brazil. Memórias do Instituto Oswaldo Cruz 97:301-305, 2002.

31. Vitral CL, Yoshida CFT, Lemos ERS, Teixeira CS, Gaspar AMC. Age-specific prevalence of antibodies to hepatitis A in children and adolescents from Rio de Janeiro, Brazil, 1978 and 1995. Relationship of prevalence to environmental factors. Memórias do Instituto Oswaldo Cruz 93:1-5, 1998.

32. Yoshida CFT, Nogueira RMR, Mercadante LAC, Pinhão AT, Schatzmayr HG. Seroepidemiological survey of hepatitis A and B, Cytomegalovirus and Herpes simplex type 2 in prime blood donors from Rio de Janeiro, Brazil. Revista de Microbiologia 18:5-11, 1987. 